Resumen por el autor, Wayne J. Atwell

La morfogénesis de la hipófisis en los anfibios caudados.

El autor ha estudiado la hipofisis en Amblystoma, Spelerpes, Necturus y Amphiuma. La hipófisis epitelial se desarrolla a expensas del ectodermo, diferenciándose en tres lóbulos: la pare anterior propia, la parte intermedia y la parte tuberosa. La parte anterior propia o lóbulo anterior propio, forma la mayor parte de la glándula y viene a rodear las superficies caudal y ventral del infundíbulo. La parte intermedia se desarrolla a expensas del extremo dorso-caudal del fundamento hipofisario primitivo. En su posición adulta está situada posteriormente al lobulo neural, penetrando entre este último y el lóbulo anterior. La parte tuberosa procede de un par de procesos que crecen hacia delante desde el resto de la glándula. Estos procesos no se separan para formar placas epiteliales separadas como sucede los anuros, sino que conservan su relación con el lóbulo anterior durante la vida del individuo.

En Necturus y Amphiuma el lóbulo anterior está considerablemente dilatado. A juzgar por estos hechos solamente, estas dos formas son las primitivas en los anfibios caudados y están bastante intimamente relacionadas con ciertos peces.

Translation by Joe6 F. Nonidez Cornell Medical College, New York 
AUTHOR'B ABSTRACT OF THIS PAPER IBgUED

BY THE BIBLIOGRAPHIC BERVICE, DECEMBER 12

\title{
THE MORPHOGENESIS OF THE HYPOPHYSIS IN THE
} TAILED AMPHIBIA

\author{
WAYNE J. ATWELL \\ Laboratories of Anatomy, Medical Department of the University of Buffalo \\ NINETEEN FIGURES
}

The pars tuberalis has been recognized as a division of the epithelial hypophysis quite distinct from either the anterior lobe proper or the pars intermedia only within the past few years. At present the developmental and adult relations of the pars tuberalis are well known for a number of the vertebrate classes, viz., mammals, birds, reptiles, and to a certain extent for the amphibia, due to the researches of Tilney, Bolk, Woerdeman, Baumgartner, Parker, the writer, and others. The question as to the presence of an homologous lobe in the hypophysis of the remaining vertebrates is one which must be settled before broad generalizations may be made with assurance. The homologies attempted by Woerdeman, for example, seemed premature, since he did not have at his command the developmental histories of the gland for the amphibia or the teleost fishes.

In a previous paper (Atwell, '18 a) the writer has described the development of the hypophysis in the anura. In these forms the pars tuberalis is developed as a pair of buds which grow nasalward and, at about the time of metamorphosis, become detached from the remainder of the epithelial portion to form two discrete epithelial plaques. A preliminary study of the development of the gland in the tailed amphibia showed certain differences to exist, one in particular being of sufficient interest to warrant a more detailed investigation.

\section{PLAN AND METHODS}

It has been the plan of the present study to follow the development of the hypophysis by close stages in one genus of the urodeles and then to compare with this certain larval and adult 
stages from other of the tailed amphibia. For the former Ambystoma was chosen. Fertilized eggs of the species A. punctatum were collected and embryos and larvae taken and preserved at frequent intervals. Older specimens were of A. punctatum, A. tigrinum, and A. jeffersonianum. For comparison, larval and adult stages of Necturus maculosus, Spelerpes bislineatus, and Amphiuma means were studied.

The fixative most often employed was Bouin's fluid, but for certain of the younger and a few of the older stages formol-bichromate or corrosive sublimate was used. In the case of the Amphiumae, vascular injection was employed in fixation, preceded by physiological saline solutions to remove the blood corpuscles. Series of sections prepared and utilized for this study total twentyeight series of Ambystoma, one of Necturus, three of Spelerpes, and two of Amphiuma. Free use was made of the Born wax-plate method of reconstruction to demonstrate the successive stages in the morphogenesis of the gland. Models were constructed at a magnification of 200 diameters for the larval stages and of 100 or, in one case, 50 diameters, for the adult stages. The drawings were made at the original magnification and have been reduced in most cases one-half off. The magnification given with the figures indicates their present actual size.

Acknowledgment is due to Miss Ida Sitler, formerly of Smith College, now of Hollin's College, Virginia, for the preparation of a number of the wax-plate reconstructions. I wish also to express my sincere thanks and appreciation to Mrs. H. H. Wilder, of Smith College, for the specimens of Spelerpes bislineatus which she kindly collected and fixed for me; likewise to Prof. Irving Hardesty for suggestions and aid in securing the specimens of Amphiuma.

\section{OBSERVATIONS}

a. Development of the hypophysis in Ambystoma

4 to 6.5-mm. embryos of Ambystoma punctatum. At the $4-\mathrm{mm}$. stage the hypophysis fundament is already well formed. In sagittal sections it is evident as a solid, wedge-shaped mass 
of cells extending dorsalward from the inner layer of the ectoderm at the cranial end of the oral pit. It lies between the wall of the neural tube and the foregut.

By the time the embryo has attained a length of $5.5 \mathrm{~mm}$. the hypophysis has become more elongated and is more tightly wedged between the brain wall and the foregut. Mitotic figures are present and the total number of cells composing the gland has increased considerably. Neither this stage nor the preceding gives satisfactory evidence to confirm a possible bilateral origin for the gland such as has been described by Kingsley and Thyng.

A 6.5-mm. embryo shows the gland united to the ectoderm by a stalwart connection. The oral plate is intact.

7.5-mm. embryo of $A$. punctatum. An approximately midsagittal section of the hypophysis region from a 7.5- $\mathrm{mm}$. embryo is shown in figure 1. The epithelial stalk, by which the gland maintains its attachment to the ectoderm, has become a slender cord of cells. The dorsal end of the gland is enlarged and clublike. It presses tightly against the caudal termination of the diencephalic wall. The notochord, at this stage, does not extend so far cephalad as in a corresponding stage in the frog tadpole, and consequently its cephalic end is not in intimate relation with either the infundibulum or the epithelial hypophysis. The oral plate is intact.

9-and 10-mm. larvae of A. punctatum. Figure $2 \mathrm{~A}$ shows a waxplate reconstruction of the hypophysis from a $9-\mathrm{mm}$. larva viewed from the ventral surface, with the caudal end below. The gland is just losing its connection with the ectoderm as its drawn-out cephalic end indicates. The detachment takes place close to the gland in such a manner that a considerable stalk is left attached to the epithelium. This is apparently retracted into the epithelium or else completely disappears. I have never noted in the Amphibia a separation of the stalk close to the ectoderm with the consequent formation of remnants, such as frequently are seen in mammals, and which may give rise to a 'pharyngeal hypophysis' or a 'parahypophysis.' There is a certain rearrangement, with more compact grouping, of the cells 
which are to form the pars intermedia. These are situated at the caudal free extremity of the gland.

12-mm. larva of A. punctatum. A wax-plate reconstruction from a larva of this stage is shown in figure $2 \mathrm{~B}$. Comparison of $A$ and $B$ of figure 2 shows that after the detachment of the gland

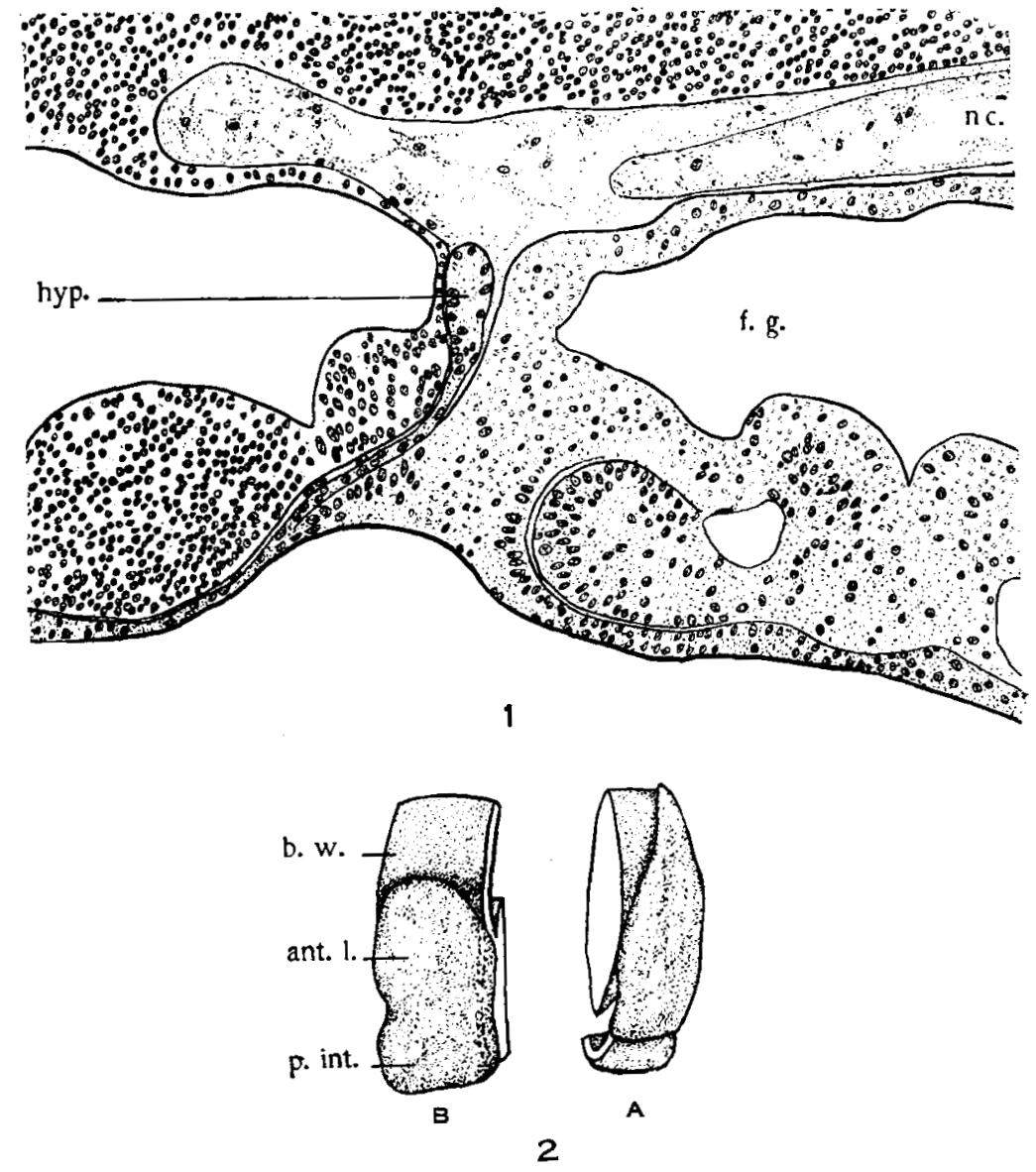

Fig. 1 Approximate midsagittal section of hypophysis region from $7.5-\mathrm{mm}$. larva of Ambystoma; nasal end at left. hyp., epithelial hypophysis; f.g., foregut; nc., notochord. $\times 100$.

Fig. 2 Wax-plate reconstructions of the epithelial hypophysis and adjacent brain wall viewed from the ventral surface. $A$, from a $9-\mathrm{mm}$. larva of Ambystoma; $B$, from a 12-mm. larva. Caudal end below. b.w., brain wall; ant.l., anterior lobe; $p$.int., pars intermedia. $\times 100$. 
from the epithelium the hypophysis becomes both relatively and absolutely shorter. The cephalic end of the gland becomes blunt and round. It appears as though some traction which previously had kept the gland drawn out and elongated had been rather suddenly relieved. The pars intermedia is more distinctly differentiated and its separation from the anterior lobe proper is indicated by grooves at the sides.

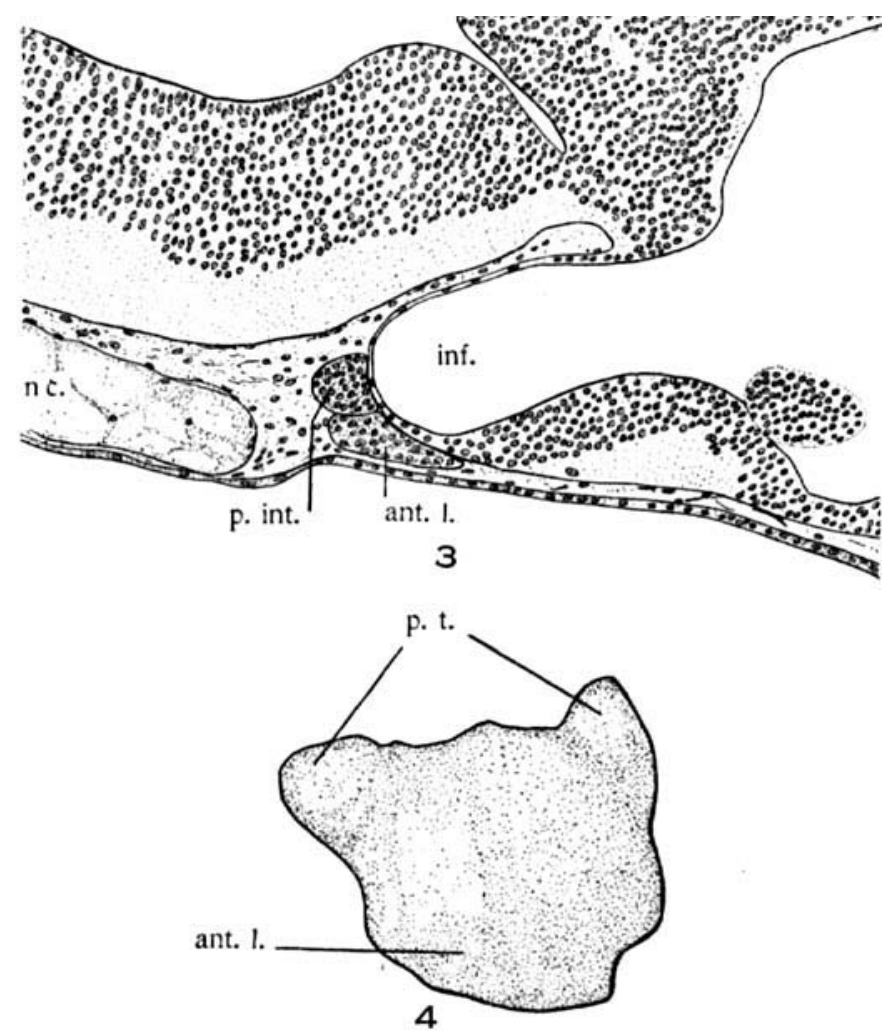

Fig. 3 Sagittal section of hypophysis region, 15-mm. Ambystoma larva. Nasal end at right. nc., notochord; inf., infundibulum; ant.l., anterior lobe; p.int., pars intermedia. $\times 100$.

Fig. 4 Ventral view of a wax-plate reconstruction of the epithelial hypophysis from a 38-mm. Ambystoma larva; caudal end below. p.t., pars tuberalis; ant.l., anterior lobe. $\times 100$. 
14- and 15-mm. larvae of A. punctatum. Between the 12-m $\mathrm{n}$. and 14-mm. stages the rupture of the oral plate occurs. Transverse sections of the hypophysis of 14-mm. larvae show a thin shelf-like lateral extension on each side of the anterior lobe proper. These are doubtless the lateral lobes which later form the pars tuberalis. A midsagittal section of the hypophysis region from a 15-mm. larva is given in figure 3.

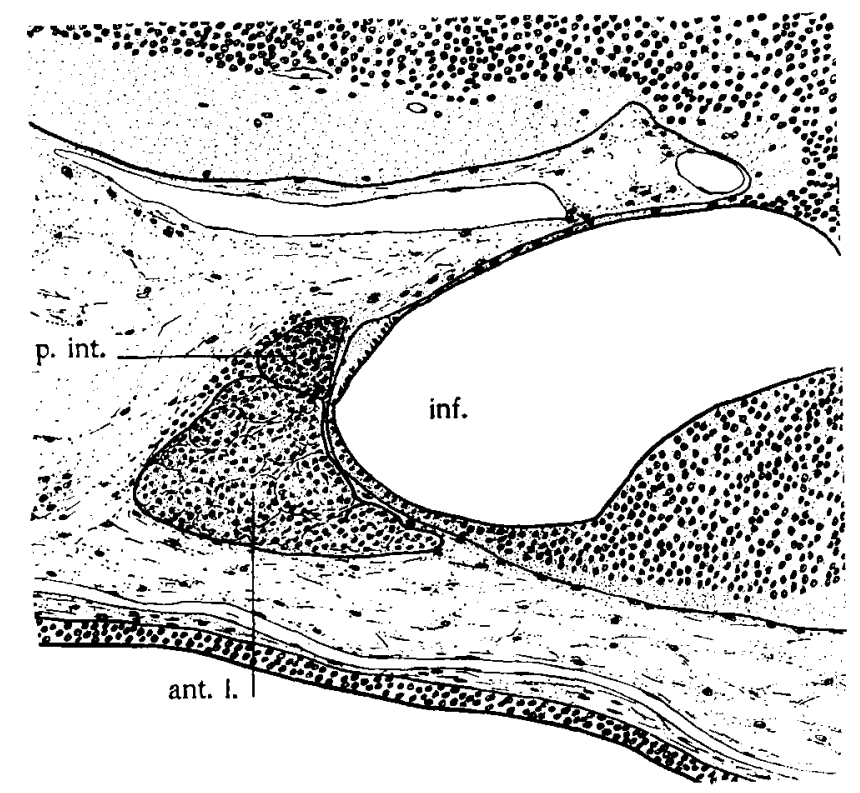

Fig. 5 Midsagittal section of the hypophysis region from a $40-\mathrm{mm}$. Ambystoma larva; nasal end at right. inf., infundibulum; p.int., pars intermedia; ant.l., anterior lobe. $\times 100$.

38-, 40-, and 60-mm. larvae of Ambystoma. Figure 4 shows a ventral view of a wax-plate reconstruction of the epithelial hypophysis from a 38-mm. larva. The two buds which compose the pars tuberalis are well differentiated. The pars intermedia cannot be seen from this surface. The reason for this is well illustrated by figure 5, which gives a midsagittal section from a $40-\mathrm{mm}$. larva. The anterior lobe is molded around the caudal end of the infundibulum in such a manner that, with 
the pars intermedia, a cup-shaped structure is formed. The pars intermedia is situated dorsal to the anterior lobe and at some distance forward from its caudal extremity. The neural lobe is apparent as a thickening of the part of the infundibular wall adjacent to the pars intermedia. The two bud-like portions of the pars tuberalis grow forward, becoming more elongated (fig. 6). The 60-mm. larva shows a considerable increase

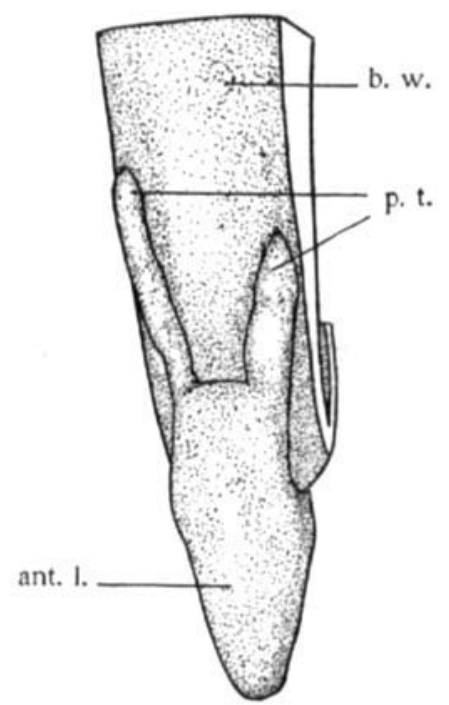

Fig. 6 Ventral view of a wax-plate reconstruction of the hypophysis from a 40-mm. larva of Ambystoma. Caudal end is below. b.w., brain wall; p.t., pars tuberalis; ant.l., anterior lobe. $\times 100$.

in the size of all parts of the gland, but the enlargement of the anterior lobe proper is especially apparent.

Adult Ambystoma jeffersonianum. The hypophysis of the adult ambystoma is shown in sagittal section in figure 7 . Three views of the wax-plate reconstruction are given in figures 8 , 9 , and 10. The anterior lobe proper is seen to be the most caudal portion of the gland. The name 'anterior lobe,' therefore, has not been applied because of the relative position of the part in the adult amphibian, but because of its homology to the corresponding lobe in the higher vertebrates. Both sections and 
reconstructions show that the pars intermedia is small. Its greatest dimension, which is from side to side, is less than the width of the anterior lobe proper. It is located dorsally and lies wedged in between the neural lobe and the anterior lobe (figs. 7, 8, and 9).

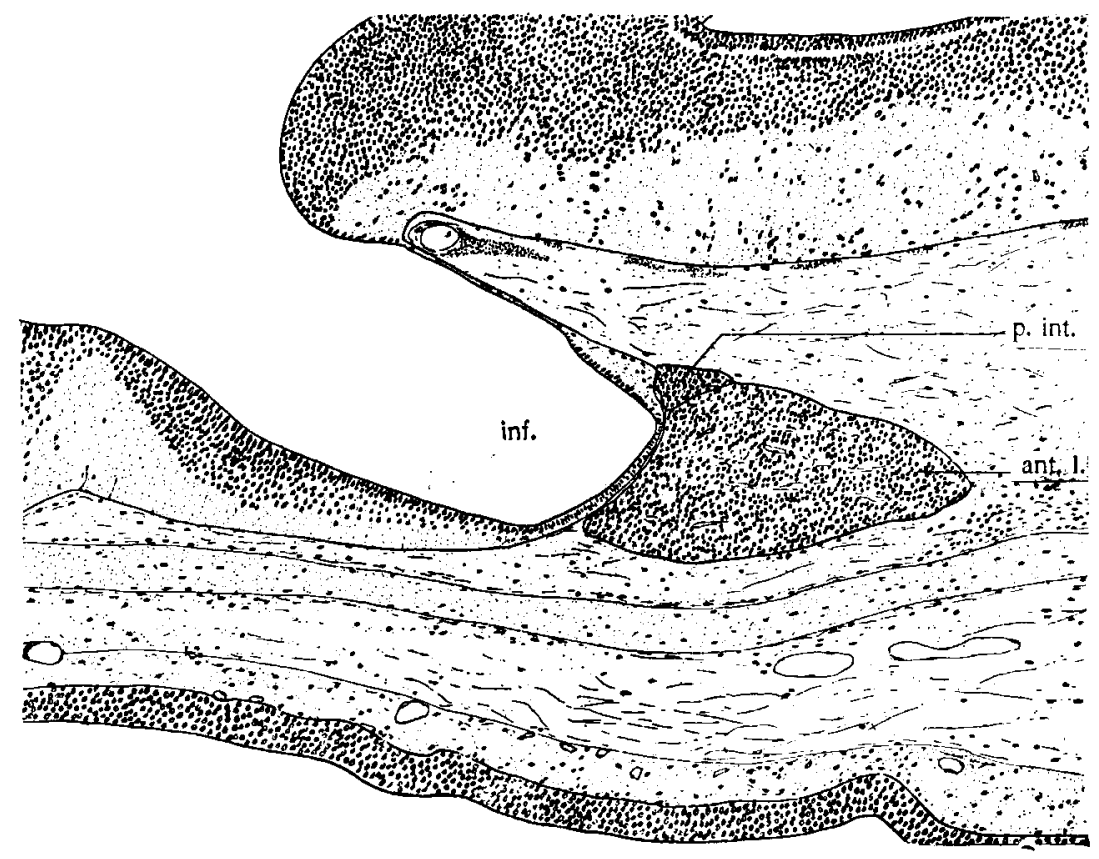

Fig. 7 Midsagittal section of the hypophysis region of an adult Ambystoma. The nasal end is at the left. inf., infundibulum; p.int., pars intermedia; ant.l., anterior lobe. $\times 40$.

The adult condition of the pars tuberalis resembles very closely the larval. As shown by figures 8 and 10, the two processes of the pars tuberalis maintain their connection with the main body of the gland. They are elongated and lie embedded in the pia mater close to the floor of the brain. These processes do not become detached, as in the frog and the toad, to form separate epithelial dises, or plaques, but remain throughout adult life as two tongue-like processes extending nasalward from the anterior lobe proper. 


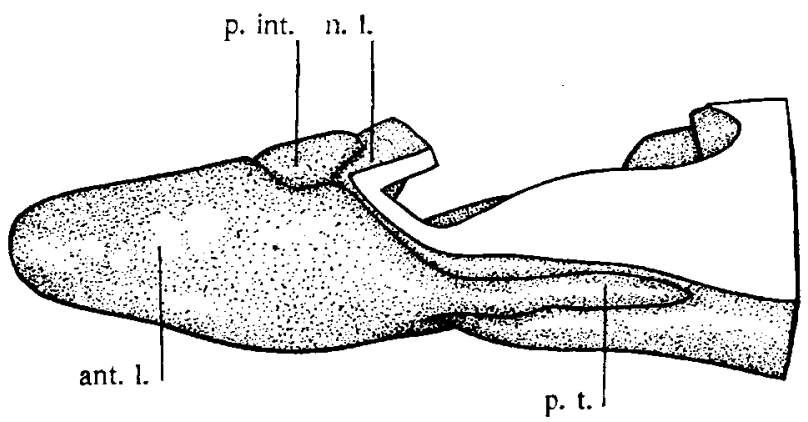

8

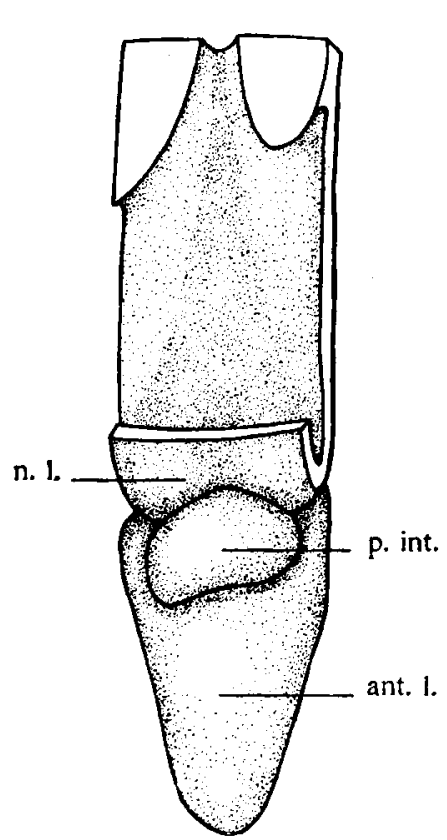

9

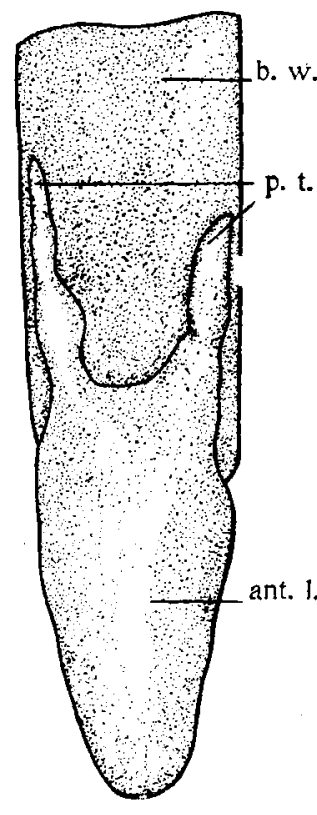

10

Figs. 8, 9, and 10 Wax-plate reconstruction of hypophysis and adjacent brain wall of an adult Ambystoma. Figure 8 views it from the right side; figure 9 is a dorsal view; figure 10 is a ventral view, caudal end below. n.l., neural lobe; p.int., pars intermedia; p.t., pars tuberalis; ant.l., anterior lobe proper. $\times \mathbf{5 0}$. 


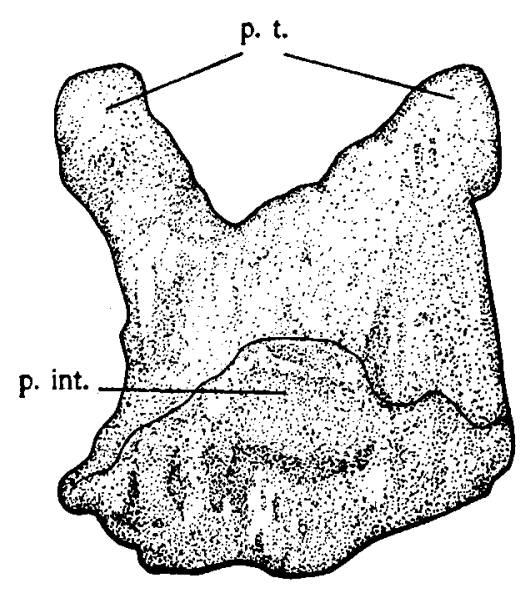

11
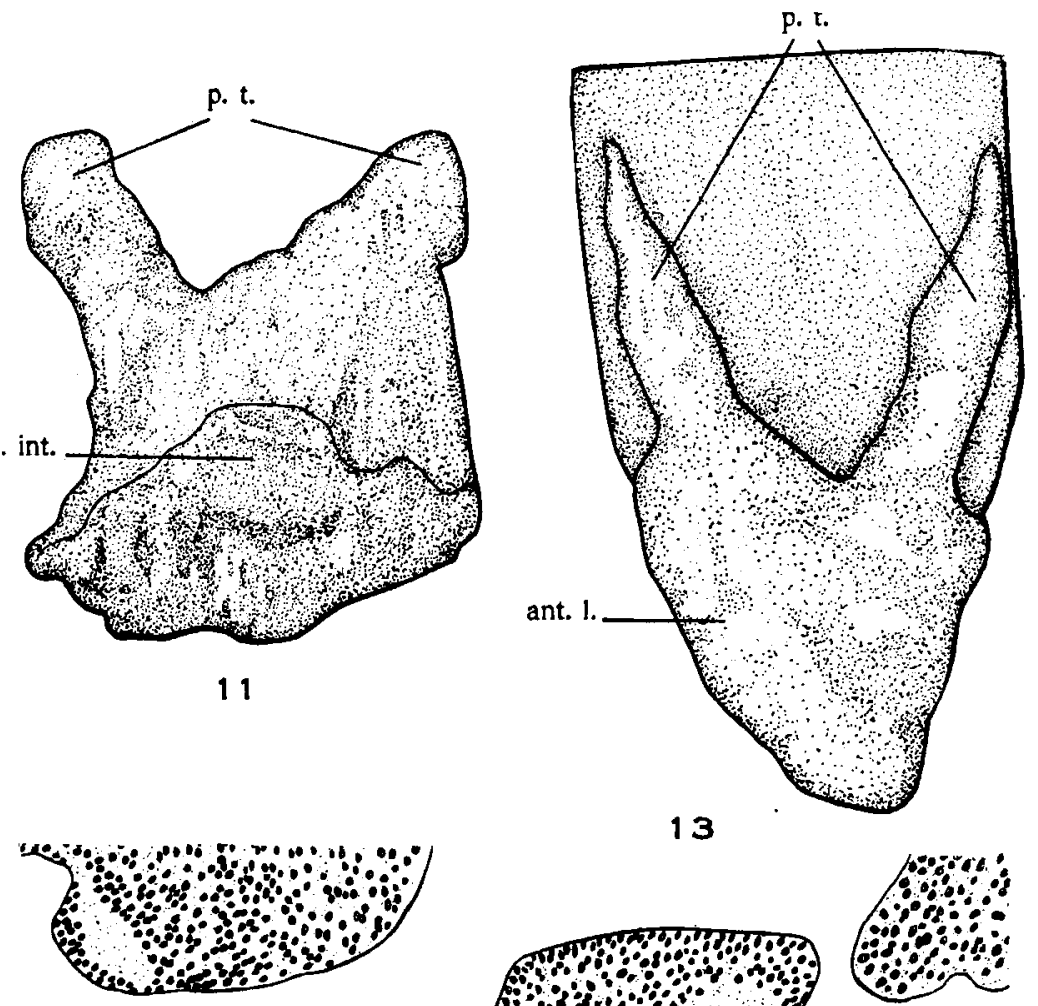

13
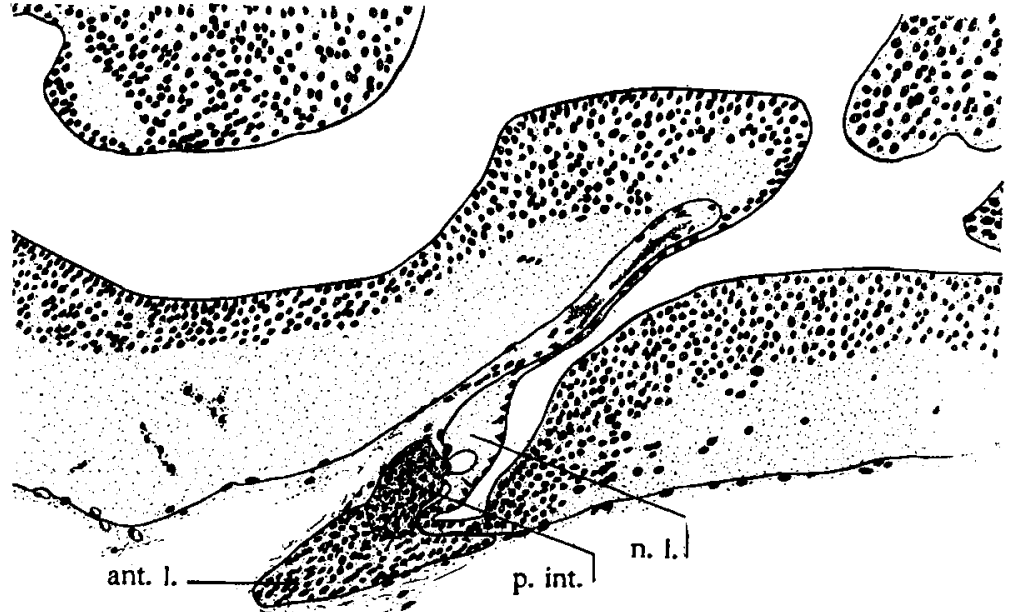

12

Fig. 11 Dorsal view of a wax-plate reconstruction of the epithelial hypophysis from a $19.5-\mathrm{mm}$. Spelerpes larva, caudal end below. p.t., pars tuberalis; p.int., pars intermedia. $\times 100$.

Fig.12 Midsagittal section of the hypophysis region from an adult of Spelerpes bislineatus, nasal end at right. ant.l., anterior lobe proper; p.int., pars intermedia; n.l., neural lobe. $\times 100$.

Fig. 13 Wax-plate reconstruction of the hypophysis of an adult Spelerpes bislineatus; caudal end below. p.t., pars tuberalis; ant.l., anterior lobe proper. $\times 100$. 


\section{b. The hypophysis of Spelerpes}

For comparison the hypophysis was studied in three other tailed amphibia, with special attention given to the adult morphology of the gland. The forms chosen were Spelerpes bislineatus, Necturus maculosus, and Amphiuma means.

The specimens of Spelerpes include a $19.5-\mathrm{mm}$. larva, a larva of the 'pre-metamorphic stage' (Wilder), and an adult. A dorsal view of a wax-plate reconstruction of the epithelial hypophysis from the younger larva is shown in figure 11 and from

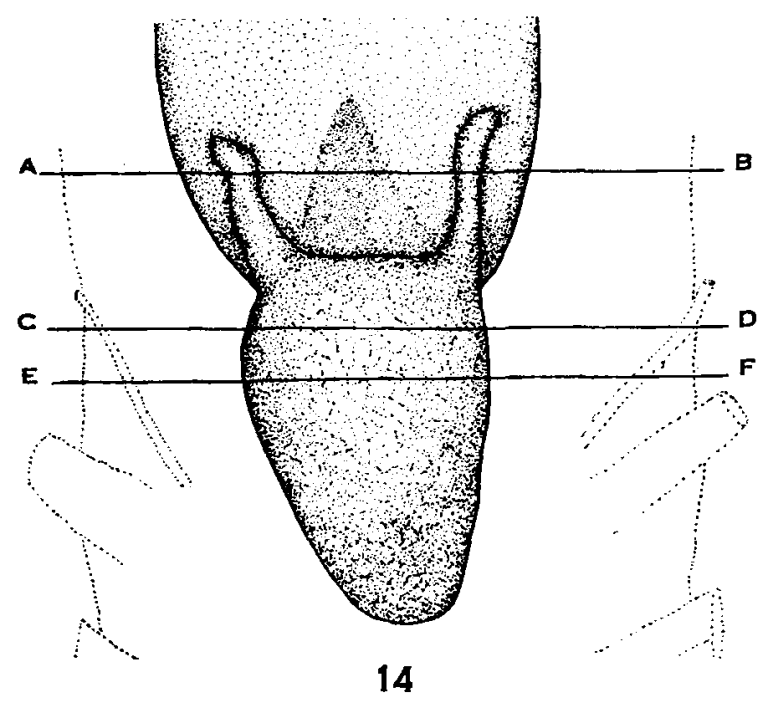

Fig. 14 Camera-lucida drawing showing a ventral view of the hypophysis of an adult of Necturus maculosus, caudal end below. $A-B, C-D$, and $E-F$, indicate planes of sections shown in figures 15,16 , and 17 , respectively. $\times 15$.

the adult in figure 13. Figure 12 presents a sagittal section of the adult hypophysis. It may be seen that the pars intermedia is relatively large. The anterior lobe proper is small and is situated almost entirely caudal to the infundibulum. Corresponding to the large size of the pars intermedia the neural lobe is also relatively large. The two components of the pars tuberalis maintain their attachment to the anterior lobe proper, even in the adult stage (fig. 13). 


\section{c. The hypophysis of Necturus}

A camera-lucida sketch of the hypophysis and adjacent brain floor in an adult is given in figure 14. The lines $A-B, C-D$, and $E-F$ indicate the positions of the transverse sections shown in figures 15,16 , and 17, respectively. As may be seen from figure 14, the two portions of the pars tuberalis remain united to the anterior lobe. The latter is elongated with its greatest dimension extending anteroposteriorly.

Figure 15 shows a transverse section through the pars tuberalis (fig. 14, $A-B$ ), which is seen as two epithelial strands lying under thickenings in the floor of the diencephalon. Between these two thickenings the infundibular floor is very thin. A more caudal section is shown in figure 16 (fig. 14, C-D). Here only the thin-walled infundibulum and the anterior lobe proper may be seen. A section somewhat farther caudalward is given in figure 17. The neural lobe, the pars intermedia, and the anterior lobe proper are seen. The neural lobe is very much sacculated, so that the infundibular cavity is cut five times in this one section. The pars intermedia is a thin strip situated between the other two parts. It is not very vascular in comparison with the anterior lobe; its nuclei are more closely crowded together, and with the commoner stains it is considerably darker in appearance. The anterior lobe contains large, thin-walled blood spaces and its cells have a cord-like arrangement.

\section{d. The hypophysis of Amphiuma}

Sections and a wax-plate reconstruction from adults of Amphiuma means (figs. 18 and 19) show the same general features as seen in the other tailed amphibia studied. Certain distinguishing features may be noted, however. The gland appears to be flattened from side to side (fig. 18) and much thicker in a dorsoventral dimension (fig. 19). In the latter respect the difference is marked when compared with Spelerpes. Also in Amphiuma the anterior lobe is relatively greater in bulk.

The pars intermedia is compact in structure and dark staining (fig. 19). The neural lobe is well sacculated, as in Necturus. 


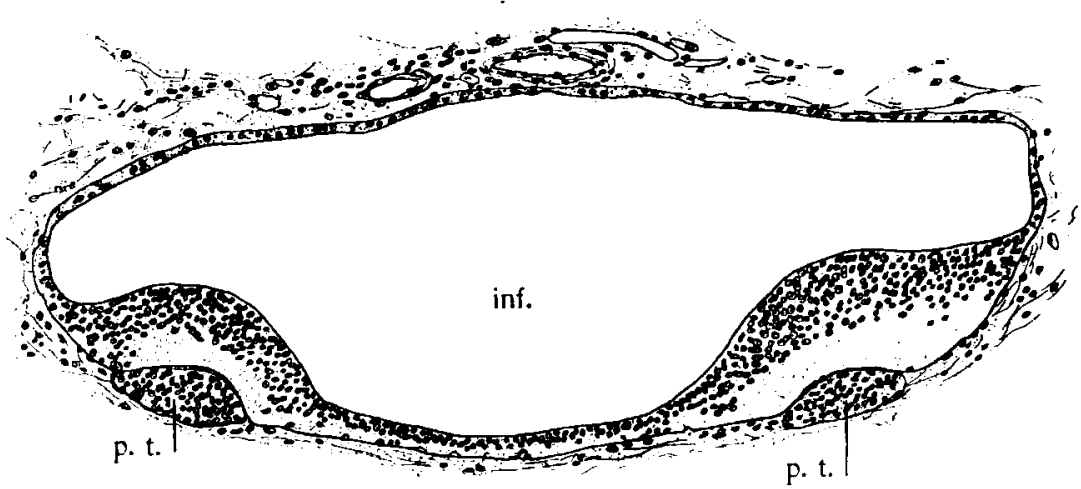

15

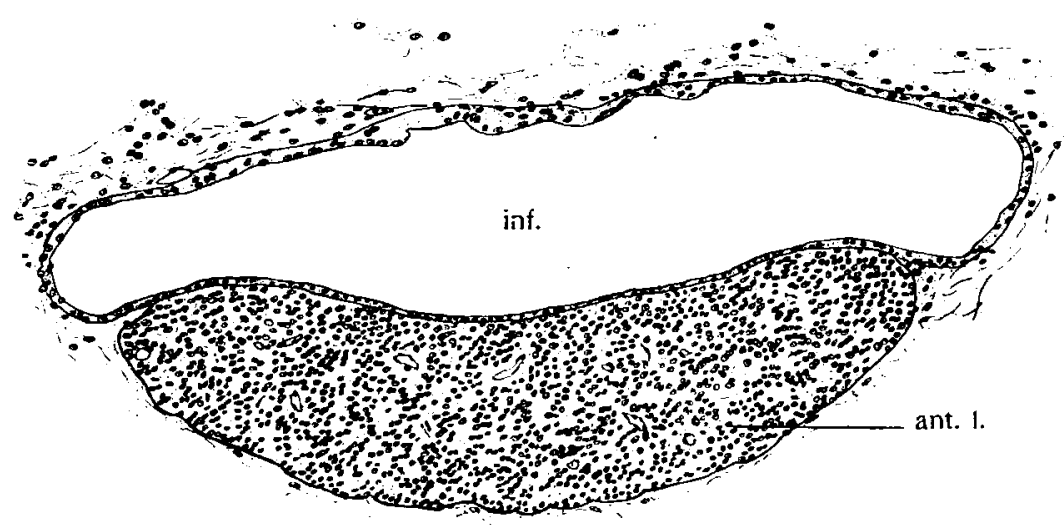

16

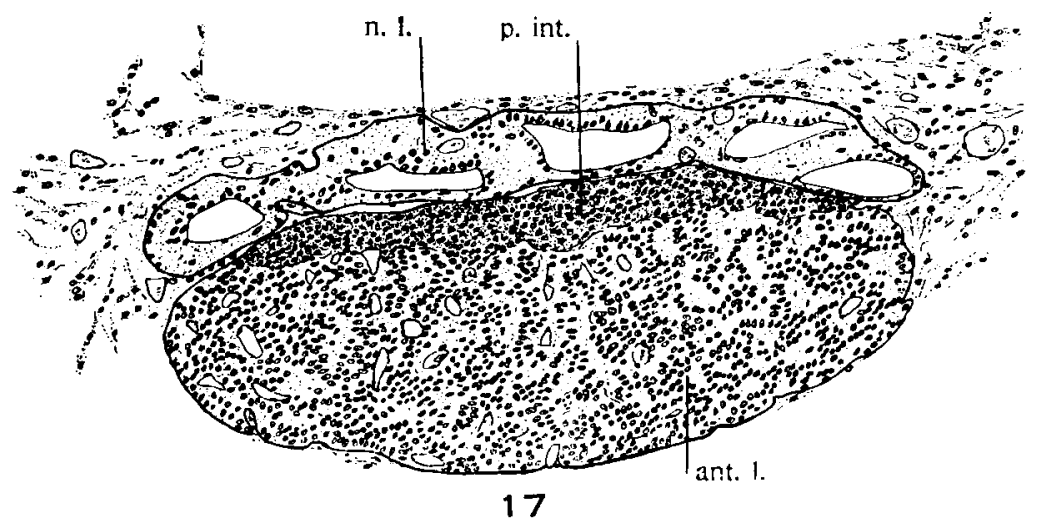

Figs. 15, 16, and 17 Transverse sections of the hypophysis of an adult Necturus, shown in the gross in figure 14. The planes of the sections are shown by the lines $A-B, C-D, E-F$, figure 14 , respectively. $\times 50$. 
The pars tuberalis, as in the other forms studied, maintains its connection with the nasal end of the anterior lobe (fig. 18).

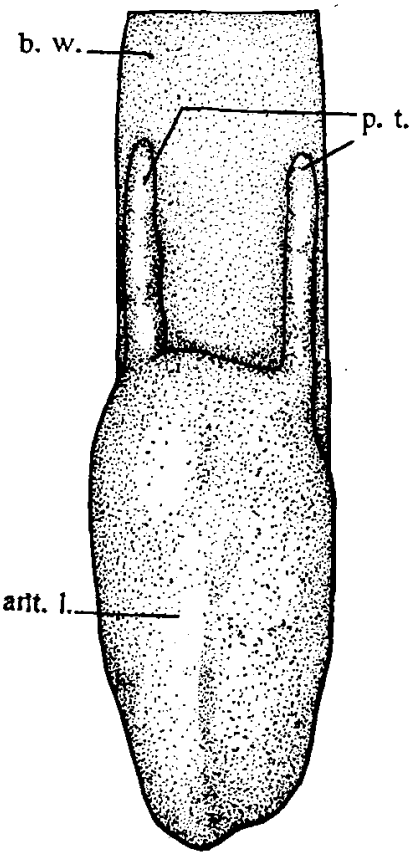

18

Fig. 18 Ventral view of a wax-plate reconstruction of the hypophysis of an adult Amphiuma, caudal end below. b.w., brain wall; p.t., pars tuberalis; ant.l., anterior lobe proper. $\times 25$.

\section{. DISCUSSION}

This study has not been primarily concerned with the early stages in the development of the hypophysis. All the evidence, however, goes to confirm the opinion that the gland is entirely ectodermal in origin, and that no contribution is made by the entoderm or the notochord, as has sometimes been claimed for the amphibia (Kupffer, '94, and Valenti, '95). The material studied has not given satisfactory evidence to confirm the statement of Kingsley and Thyng ('04) that the hypophysis has a bilateral origin in Ambystoma. 
The hypophysis breaks loose from the ectoderm in amphibia a considerable time before the rupture of the oral plate. This is the reverse order from that obtaining in birds and mammals where the oral plate ruptures early and the hypophysis maintains its connection with the ectoderm until much later.

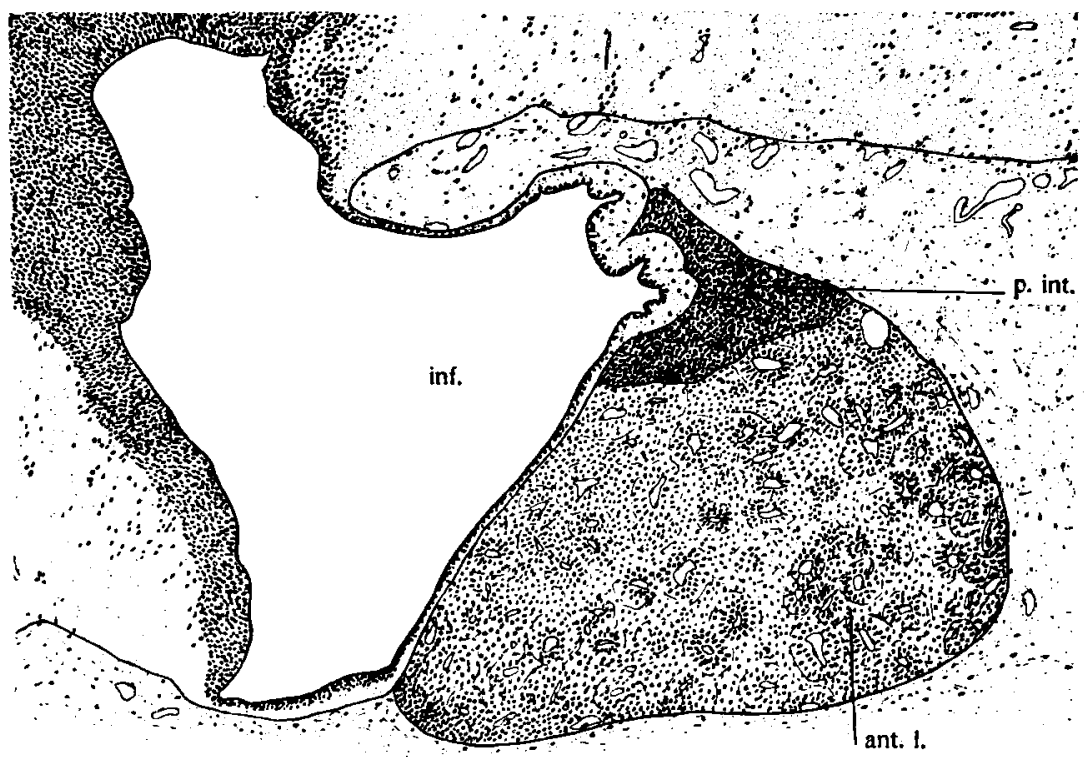

19

Fig. 19 Midsagittal section of the hypophysis region of an adult Amphiuma. Nasal end at left. inf., infundibulum; p.int., pars intermedia; ant.l., anterior lobe proper. $\times 30$.

That the two tongue-like processes attached to the nasal end of the anterior lobe are to be considered homologous with the pars tuberalis in the higher vertebrates seems to me very certain. They are similar in all respects to the processes seen in the larval stages of the anura (cf. Atwell, '18 a).

These structures have been noted by Stendell ('14), who describes them in these words:

Bei den Urodelen und Anuren kann noch ein besonderer Hypophysenteil unterschieden werden, der hier Erwähnung finden möge. 
Er liegt im allgemeinen von den übrigen Hypophysenabschnitten, dem Haupt- und Zwischenlappen, getrennt weiter vorn fast unter dem Chiasma opticum, dem Hirnboden dicht angepresst (Fig. 43, 44 und 26c). Er ist durchaus drüsiger Natur und zum Darmteil gehörig. Meistens ist er paarig entwickelt in Form zweier symmetrisch zu beiden Seiten der Medianen gelegener, flach-linsenförmiger Zellhäufchen. Dieser Hypophysenteil ist Pars anterior, auch Pars chiasmatic agenannt worden.

Stendell is uncertain whether this pair of processes should be classed with the anterior lobe proper or the pars intermedia. He has not attempted to homologize it with the pars tuberalis, since the individuality of this lobe was not recognized by him for any of the vertebrate classes.

The most striking feature to be observed in comparing the hypophysis of the urodeles and the anura is that in the former the two tongue-like processes of the pars tuberalis do not become detached from the anterior lobe proper, even in adult life. It will be recalled that in the anura the processes become detached at the time of metamorphosis and form two discrete epithelial plaques. This peculiarity was noted by Stendell for at least one form. He states: "Ferner scheint die Hypophyse von Proteus anguineus in dieser Beziehung primitive Verhältnisse zu zeigen. Bei ihr nämlich bleibt jener vordere Teil zeitlebens als zungenförmige Verlängerung an dem Hauptlappen des Darmteils hängen."

That this condition is a constant one for the tailed amphibia seems certain, since it is also found to obtain in Ambystoma, Spelerpes, Necturus, and Amphiuma. It is interesting to speculate upon a possible relationship between this apparently 'primitive' condition of the hypophysis and the retention of the tail throughout adult life. Is there anything more than coincidence to be assigned to the fact that in the higher Amphibia when the tail is lost at metamorphosis, the pars tuberalis likewise becomes detached?

It must be noted that the peculiar detached condition of the pars tuberalis in the adult anura is not general for the higher vertebrate classes, since in birds and mammals the lobe is usually found connected with the remainder of the gland. It is 
often detached, however, and sometimes disappears entirely in certain reptiles (Baumgartner, '16).

The sacculations of the neural lobe, noted in two of the forms studied, were not observed for the frog or the toad (Atwell, '18 a). In this respect the hypophysis of the tailed amphibia is the more closely related to that of the fishes, where in certain forms, notably the elasmobranchs, the sacculation of the neural lobe and its interdigitation with the pars intermedia are very extensive.

\section{SUMMARY}

In the tailed amphibia the epithelial hypophysis is developed from the ectoderm and differentiates into three lobes: the pars anterior proprior, the pars intermedia, and the pars tuberalis. The pars anterior proprior, or anterior lobe proper, forms the main bulk of the gland and comes to lie caudal and ventral to the infundibulum. The pars intermedia is developed from the dorsocaudal extremity of the early hypophysial fundament. In its adult position it lies caudal to the neural lobe and dorsal to the anterior lobe. The pars tuberalis develops from a pair of processes which grow forward from the remainder of the gland. These processes do not become detached to form separate epithelial plaques as in the anura, but maintain their connections with the anterior lobe throughout life. The neural lobe is considerably sacculated in Necturus and Amphiuma. Judging from this criterion alone, these two forms are primitive and are rather closely related to certain of the fishes. 


\section{LITERATURE CITED}

Arwell, W. J. 1918 a The development of the hypophysis of the Anura. Anat. Rec., vol. 15, p. 73.

$1918 \mathrm{~b}$ The development of the hypophysis cerebri of the rabbit (Lepus cuniculus L.). Am. Jour. Anat., vol. 24, p. 271.

BAUMGARTNER, E. A. 1916 The development of the hypophysis in reptiles. Jour. Morph., vol. 28.

BoLx, L. 1910 Over de ontwickkeling der Hypophyse in het byzonder by Tarsius en den Mensch. Verslag. d. Kon. Akad. v. Wetensch. Amsterdam.

Kingsiey, J. S., And Thyng, F. W. 1904 The hypophysis in Amblystoma. Tufts College Studies, Scientific Series, vol. 1, no. 8, p. 363.

Kupfrer, C. V. 1894 Die Deutung des Hirnanhanges. Sitz. Ber. d. Gesellsch. f. Morph. u. Physiol. zu München, S. 59 .

PARKer, K.M. 1917 The development of the hypophysis cerebri, preoral gut, and related structures in the Marsupialia. Jour. Anat., vol. 51, part 3.

Stendell, Walter 1914 Die Hypophysis Cerebri, Achter Teil in Oppel's Lehrbuch der vergleichenden mikroscopischen Anatomie der Wirbelthiere.

Tilney, Frederick 1913 An analysis of the juxta-neural epithelial portion of the hypophysis cerebri, with an embryological and histological account of an hitherto undescribed part of the organ. Internat. Monatschr. f. Anat. u. Physiol., Bd. 30.

Valenti, G. 1895 Sullo sviluppo dell' ipofisi. Anat. Anz., Bd. 10, S. 538.

Woerdeman, M. W. 1914 Vergleichenden Ontogenie der Hypophysis. Arch. f. mikr. Anat., Bd. 86. 